\title{
What Hamblin's Book Fallacies Was About
}

\author{
Jim MACKENZIE
}

Faculty of Education and Social Work A35

University of Sydney

Sydney

Australia 2006

jim.mackenzie@sydney.edu.au

\begin{abstract}
The discussion of formal dialogue in Chapter Eight of Hamblin's book Fallacies is not so much an outgrowth of the preceding discussion of fallacies; rather, fallacies provided an illustration of how otherwise intractable questions about logic could be transformed by being considered in the context of dialogue. Hamblin's view that this is the best way to understand logic can be seen as combining the strengths of the kind of philosophy which emphasised formal logic, as exemplified by Hamblin's teacher Karl Popper, with those of the kind of philosophy which emphasised the variety of ordinary language, as inspired by the later work of Ludwig Wittgenstein.
\end{abstract}

Résumé: La discussion sur le dialogue formel dans le chapitre huit de Fallacies de Hamblin n'est pas tant un développement de la discussion précédente sur les sophismes, mais ceux-ci plutôt illustrent comment transformer des questions sur la logique dans le contexte d'un dialogue et ainsi éviter des problèmes difficiles. Si on peut voir cette transformation comme un agencement des approches philosophiques qui s'appuient sur la logique formelle, comme en témoigne Popper, l'enseignant de Hamblin, et des approches philosophiques qui insistent sur la variété du langage ordinaire, inspirées par les travaux postérieurs de Ludwig Wittgenstein, on peut saisir pourquoi Hamblin croit que ceci est la meilleure façon comprendre la logique.

Keywords: Dialogue, Fallacies, Formalisation, Logic, Ordinary language philosophy

I finished my undergraduate degree at Monash University and joined Charles Hamblin's seminar at the University of NSW in March, 1968. Phil Staines from the University of Newcastle joined at the same time, and Vic Dudman and Neil Harpley were established members. Hamblin's book Fallacies would be published in 1970, but the seminar discussions rarely concerned fallacies. This may have been because Hamblin had been working for so long and so closely with those ideas that he was now ready to turn elsewhere. But I shall argue that the book was only part of a much broader program, other parts of which occupied us in the seminars. Hamblin never explicitly discussed the writing of Fallacies with me, and what follows is an attempt to ex- 
plain how the book fitted into his overall project as a logician, drawn from his published works and from what I remember of his contributions to the seminar.

The topic which, from various points of view, most often occupied the seminars was dialogue, and specifically attempts to understand questions of philosophical logic by considering them in the context of dialogue. By dialogue was meant the sort of meeting, without a chairman but nevertheless a distinction between substantive and procedural points, for simplicity with only two participants, which we find in chapters 8 and 9 of Fallacies, which occupies many stretches in Plato's dialogues, and which is approximated by the medieval Obligation Game (on which see more recently Dutilh Novaes, 2007) and in multiagent systems (McBurney et al., 2010) Every logical question was considered as part of a linguistic interaction between at least two people. ${ }^{1}$

Hamblin's book Fallacies was an intellectual phenomenon for two reasons. In the first place, it broke completely new ground. It was the first full-length scholarly book on fallacies since the Middle Ages, and arguably since Aristotle's Sophistical Refutations itself (see Hamblin, 1970, pp. 12-13). It was thus a thorough investigation of a field of inquiry which had not previously been explored in such detail. In the second place, it arrived in college bookstores just as an educational niche opened up which it happened to fill, what would come to be called informal logic. During the 1960s authorities had been calling for, or even prescribing, courses of study in critical thinking or reasoning or argumentation. Leo Groarke describes the historical context in which informal logic developed in the following terms:

Informal logic is a recent discipline. It has some precedents in those nineteenth century works on Logic and Rhetoric which aim to raise general standards of reasoning through public education (see, e.g., Whatley [scil. Richard Whately] [1830], [1844]). But informal logic is a child of the 1960s. It is ultimately rooted in its social and political movements, which were characterized by a call for an education more "relevant" to the issues of the day.

\footnotetext{
${ }^{1}$ On one occasion, Hamblin remarked that Quine was an imperialist. Political sloganeering was not usual in the seminar, but under questioning he revealed that what he meant was that Quine in Word and Object (1960) chapter two considers only the attempts by the field linguist to learn the native's language, and ignores the fact that the native would surely be equally making attempts to learn the linguist's language. In any linguistic exchange, both sides have to be taken into account. The various topics considered in the seminar, whether dealing with tense logic, indexicals, referential opacity, etc., were always discussed in a dialogical (two-way) setting.
} 
In logic, and especially the teaching of logic, this fostered the attempt to replace the artificial examples of good and bad argument that tended to characterize earlier logic texts (e.g., Copi [1957]) with instances of reasoning, argument and debate taken from newspapers, the mass media, advertisements and political campaigns (Kahane [1971] is a good example of this trend).

One significant impetus in the development of the informal logic and critical thinking movements was a 1980 California State University Executive Order that required that post secondary education include formal instruction in critical thinking. According to the order: "Instruction in critical thinking is to be designed to achieve an understanding of the relationship of language to logic, which should lead to the ability to analyze, criticize, and advocate ideas, to reason inductively and deductively and to reach factual or judgmental conclusions based on sound inferences drawn from unambiguous statements of knowledge or belief' (Dumke [1980], Executive Order 338). (Groarke, 2008). ${ }^{2}$

In many institutions the teaching and often the design of these courses fell to young lecturers or graduate students in philosophy departments. But the textbooks available to them were sadly inadequate, as indeed Hamblin showed in his first chapter. Doug Walton recalled:

Those of us, like me, who were asked or told by their departments to teach a section of logic on the subject of fallacies before or during the early seventies felt the impact of the current state of knowledge in this area quite dramatically. Our more serious and gifted students pointed out to us, with some regularity and sometimes with satisfaction, that the examples of "fallacious" arguments we were using were just not convincing.

${ }^{2}$ Hamblin traced (p. 195) the term "formal fallacy" to Richard Whately (1848, Book III), but he remarked of the then newish name "informal logic":

We might remind ourselves that some modern books [In a footnote, Hamblin here cites Irving M. Copi's Introduction to Logic, Chapter 3] even refer to a large class of them specifically as "Informal Fallacies". The contrast of 'informal' with 'formal' suggests the contrast of loungesuit with dress-uniform, and this was never the burden of the older 'formal'-'material' dichotomy; but it marks a greater readiness to acknowledge a fundamental difference than, for example, one could read into Whately. (Hamblin, 1970, p. 205).

The fallacious appeal to lack of formal validity in attempting to convict an argument of fallacy would later be emphasised by Gerald Massey (1981), and see Staines (1995); but the relations between an argument in ordinary language and any formal structure presented as a "symbolisation" of it were thrashed out in the seminar (Staines, 1981). 
This was a sobering challenge to young and serious instructors, armed only with the given knowledge in their field. How could you convince your students that here was a field worth taking seriously? (Walton, 1991, p. 356.)

Hamblin obviously wrote his book without foreseeing the context in which it would take its place, a context which would come into being only after it had been published. It might be supposed that he had begun with an interest in fallacies, and developed from that to a new view of logic. This is precisely the wrong way round (see 1970, p. 191). The appearance of formal dialogue in Chapter 8 of Fallacies was not an outgrowth of his interest in fallacies; rather fallacies provided an illustration of, or vestibule to, how otherwise intractable questions about logic could be transformed by being considered in the context of dialogue. To understand what he was trying to do with the book, we must look rather at the philosophical landscape in which he wrote it in the years before its publication. Hamblin's work combined the strengths of two rival philosophical schools.

As the 1950s drew to a close, analytic philosophy was divided between two schools. ${ }^{3}$ The more traditional, more formal school regarded the question of linguistic meaning as a matter of relations between linguistic expressions and the world, to be explored using the resources of mathematical logic as developed by Frege, by Whitehead \& Russell, and by their successors. In the extreme, it held that logic is the study of an abstract reflexive, transitive relation with the subformula property (Hacking, 1979). Opposed to it was a school more rooted in everyday life and emphasising the variety of acts which speakers perform in their interactions with each other. Wittgenstein's Tractatus Logico-Philosophicus (1921) had been a classic of the first, formal, school, and his own subsequent self-criticism played a great part in the birth of the second school. Followers of the first school regarded the second, ordinary language, school as imprecise, unscientific, and woolly. ${ }^{4}$ Followers of the second school regarded the first as ignoring the richness and multiplicity of real language in favour of idealised abstract structures. The depth of the antagonism between the two schools can be seen by recalling the response to Gellner's book Words and Things (1959). This work was a powerful broadside by a young member of the first school against the second (see Lessnoff, 2002, pp. 2-4), and appeared with a preface by Bertrand Russell. Gilbert Ryle as

\footnotetext{
${ }^{3}$ It should be unnecessary to say that within each school there was great diversity and disagreement. We are talking about philosophers here.

4 "Reviewers in JSL [the Journal of Symbolic Logic] often complained with some acerbity that the writings of British philosophers on logical topics are insufficiently formalized to be discussable." (Passmore, 1966, p. 592, n. 5.)
} 
Ryle as editor of the journal Mind refused to have the book reviewed; Russell wrote a letter to the Times complaining about this, and the resulting correspondence continued in the newspaper for nearly three weeks. The kerfuffle provoked Ved Mehta, an English-educated Indian working for the New Yorker, to come to England and interview the various philosophers involved, interviews later published in his book The Fly and the Fly-Bottle (1963).

Hamblin was connected with the first, formal, school as a former pupil of Karl Popper-his work on probability is acknowledged in Appendix *ix to Popper's The Logic of Scientific Discovery (1959, p. 402, n. 2; p. 403 n. 4; p. 404). Popper was an admirer of Bertrand Russell and like Russell had little time for ordinary language philosophy. Popper famously advocated the refutation of existing views and bold conjecture as the most productive approach (one hesitates to say "method") in science and intellectual life. Popperians should seek topics in their discipline with which there was a general dissatisfaction, topics which seemed clearly within the domain of the discipline but whose treatment by existing theories was not as one might wish, the untidy corners of the discipline, the regions of anomaly and discomfort, and then attempt on the one hand to refute whatever was said about them and on the other hand to develop bold conjectural alternatives. Hamblin's discipline was logic; and fallacies constituted a very untidy area of logic:

The truth is that nobody, these days, is particularly satisfied with this corner of logic. The traditional treatment is too unsystematic for modern tastes. Yet to dispense with it, as some writers do, is to leave a gap that no one knows how to fill. We have no theory of fallacy at all, in the sense in which we have theories of correct reasoning or inference. Yet we feel the need to ticket and tabulate certain kinds of fallacious inference-process which introduce considerations falling outside the other topics in our logic-books. (Hamblin. 1970 p. 11, his emphasis.)

Hamblin's interest was in the "considerations falling outside" conventional logic, rather than on ticketing and tabulating fallacies. Popper's influence may have contributed to Hamblin focusing on the area of fallacies as a site of possible anomalies in the conventional wisdom of logic.

Unusually for a former student of Popper, Hamblin called himself a Wittgensteinian. In Fallacies (p. 285 n.), he refers to "the best examples of dialectical analysis" as Wittgenstein's Brown Book (1958). He was thereby allying himself not with the first formal school but with the second ordinary language 
school; though in investigating the variety of speech acts he would not abandon the power of formalisation.

Wittgenstein and Popper were in some ways alike. Both grew up in Vienna, both were of Jewish descent, both had been closely involved with the Vienna Circle though neither had been a member of it (Uebel, 2010, § 2.1), both had sought refuge from Nazism in the West, and both had ultimately settled in Britain. They also agreed about some central philosophical doctrines. First, both emphasised that language comes in sentence, or speech act, sized bits. Wittgenstein said, "We may say: only someone who already knows how to do something with it can significantly ask a name" (1953, I § 31d, p. 15 $)$. Popper illustrated his acceptance of this doctrine by appeal to a diagram which appears several times in his works, several times, for example, 1960, § xii, p. 19-20. Second, both of them opposed relying on a notion of belief in seeking philosophical understanding. Wittgenstein suggested, "Ask yourself: What does it mean to believe Goldbach's theorem? What does this belief consist in? In a feeling of certainty as we state, hear, or think the theorem? (That would not interest us.)" (1953, I. § 578a, p. 152 ${ }^{\mathrm{e}}$.) "We should say that we had told the Frenchman what I believed if we translated my words to him into French. And it might be that thereby we told him nothing - even indirectly_-about what happened 'in me' when I uttered my belief. Rather, we pointed out to him a sentence which in his language holds a similar position to my sentence in the English language." (Brown Book $\S 8$, p. 147. $)^{5}$ Popper said flatly that he is "not a belief philosopher" (1971, p. $25 ; 1974$, p. 115). Hamblin preferred "accepted" to "believed", (1970, p. 246, and see also Mackenzie \& Staines, 1999). ${ }^{6}$

\footnotetext{
${ }^{5}$ The rejection of beliefs was an instance of Wittgenstein's scepticism about inner or mental processes: "An 'inner process' stands in need of outward criteria." (1953, I $\S 580$, p. $153^{\mathrm{e}}$.) "The thing in the box has no place in the language-game at all; not even as a something: for the box might be empty. No, one can 'divide through' by the thing in the box: it cancels out, whatever it is." $\left(1953, \mathrm{I} \S 293, \mathrm{p} .100^{\mathrm{e}}\right.$.) This scepticism led to the Wittgenstein of the Investigations being regarded as a behaviourist by some of his early critics (see 1953, I §§ 307-8, pp. 102-3 ${ }^{\mathrm{e}}$ ).

6 We have a natural tendency to think of these various linguistic actsmaking an assertion, expressing a thought - as the external expression of an interior act of adopting a particular mental attitude. ... The analysis of these interior acts and events is a matter of epistemology, not of logic; but the linguistic acts should be classified as conventional actions, not as the external expression of interior states. Assertion, for example, is to be explained in terms of the conventions governing the use of those sentences which are understood as having assertoric force, not as the utterance of a sentence with the intention of expressing one's interior act of judgment (or interior state of belief) that it is true." (Dummett, 1973, p. 311, his emphasis.)
} 
Third, neither Wittgenstein nor Popper shared the fear of normativity then widespread and presumably inherited from the logical positivists, which led students of language and compilers of dictionaries to proclaim absurdly that their enterprise was purely descriptive. For Wittgenstein, meaning was intimately connected with rule following and adopting a form of life (1953 I, $\S 190$, p. $77^{\mathrm{e}} ; \S 198$, p. $80^{\mathrm{e}} ; \S 202$, p. $81^{\mathrm{e}} ; \S 206$, p. $\left.82^{\mathrm{e}}\right)$. For Popper, it is our determination to reject contradictions that leads to intellectual progress $(1940$, p. 317$)$. Like Frege, ${ }^{7}$ he took it that logic does not tell us what people believe, but what they ought to believe. We can see each of these three accepted doctrines in Hamblin's work. In "Mathematical models" (1971) and other presentations of dialogue games, Hamblin took the task to be to define within the set $D$ of possible dialogues a set $K$ of legal dialogues (1971, p. 132). One began with what was assumed to have been a legal (permissible) dialogue up to a given point, and then examined what was required for the next event to result in the continuation being a legal (permissible) dialogue whose length was one greater. Thus the rule that Questions must be answered was framed as, no legal dialogue of length $n$ has as its second-last event a participant $A$ saying a question unless it has as its last event another participant (say, $B$ ) saying something which is an answer (as defined in the rules) to that question. In the simplest case, if a participant says something of the form "Is it the case that $p$ ?", then the next event must have a different speaker and be one of the set $\{" p$ ", "It is not the case that $p$ ", "I'm not sure that $p$ " . (See further Hamblin, 1970, rule S2 on p. 266; and 1971, rule $R_{5}$ on p. 147.) The rules of dialogue dealt with speech-act (sentence) sized units. Appeals to belief and other inner states played no part in the theory of formal dialogue. And logic not only grew from dialogue, but it was unashamedly normative, indeed prescriptive.

Hamblin's focus on linguistic acts as conventional actions (as Dummett would later, in the passage just quoted, recommend) may have owed something not only to Wittgenstein and to Popper, but to Hamblin's own understanding of computers. He was an early advocate of reverse Polish notation for computers as suited to their nature as push-down automata (McBurney, 2008). That focus made his work directly applicable to interactions not only among people but between people and computers and among computers (McBurney et al., 2010).

${ }^{7}$ According to Frege, the laws of logic are the laws of thought "only if we mean to assert that they are the most general laws, which prescribe universally the way in which one ought to think if one is to think at all" (1893, p. xv $=1967$, p. 12). Indeed, "Anyone who has once acknowledged a law of truth has by the same token acknowledged a law that prescribes the way in which one ought to judge, no matter where, or when, or by whom the judgment is made" (1893, p. xvii $=1967$, p. 15.). 
Nevertheless these two philosophers did not have a high regard for one another. Popper said dismissively "Russell read the Philosophical Investigations without deriving any enlightenment from it. So did I, I must admit" (in Magee, 1971, p. 138). Among Popper's students, it was known that "There could be no greater public expression of loyalty to him [scil., Popper] than to lunge at Wittgenstein" (Agassi, 2008, p. 170). Wittgenstein and Popper seem to have met in person only once, and that meeting ended unfortunately (Edmonds \& Eidinow, 2001).

As a former student of Popper, Hamblin would not be attracted by Wittgenstein's theoretical quietism (see Wittgenstein, 1953 , I $\S 126$, p. $50^{\mathrm{e}}$ ) and would not easily give up systematic philosophising. ${ }^{8}$ He was also a classical scholar who read Greek and Latin, ${ }^{9}$ and both a logician and a historian of logic. Hamblin's Wittgensteinianism was of a heterodox kind, and in some ways can be seen as uniting the strengths of the Popper and the formalising school and of the later Wittgenstein and the ordinary language school.

The study of dialectical systems can be pursued descriptively, or formally. In the first case, we should look at the rules and conventions that operate in actual discussions: parliamentary debates, juridical examination and cross-examination, stylized communication systems and other kinds of identifiable special context, besides the world of linguistic interchange at large. A formal approach, on the other hand, consists in the setting up of simple systems of precise but not necessarily realistic rules, and the plotting of the properties of the dialogues that might be played out in accordance with them. Neither approach is of any importance on its own; for descriptions of actual cases must aim to bring out formalizable features, and formal systems must aim to throw light on actual, describable phenomena. As a matter of emphasis, however, I shall lean towards a formal approach in what follows, since the practical material we aim to illumi-

\footnotetext{
${ }^{8}$ Nor would he surrender the ground of formal systems.
}

For, although there are reasons for thinking that some of the phenomena of Logic are outside the bounds of the kind of formal system in which logicians, ancient or modern, have preferred to formulate their theories, there are many who do not think this and whom we must meet on their own ground (1970, p. 192).

${ }^{9}$ The posthumously published guide Hamblin edited to Languages of Asia and the Pacific "(of course) had some thirty authors" (1984, p. vi) who are listed in its introduction. And he confessed to being unable to decipher photocopies of medieval manuscripts with their complex abbreviatory marks. Even so, his linguistic abilities were extraordinary, and he sometimes failed to realise that others (including students) did not share them. 
nate-fallacious argumentation-has already been sufficiently described. (Hamblin, 1970, p. 256, his italics.)

Hamblin adopted some of the central insights of Wittgenstein's later work. One is that we should look for the use rather than the meaning of words and linguistic expressions. "The meaning of a phrase for us is characterized by the use we make of it. The meaning is not a mental accompaniment to the expression." (p. 65 of The Blue Book) "For a large class of casesthough not for all - in which we employ the word 'meaning' it can be defined thus: the meaning of a word is its use in the language" $\left(1953, \mathrm{I} \S 43\right.$, p. $\left.20^{\mathrm{e}}\right)$. Another, following on from the first, is that we do many things with language, and that no one of them is central. Language has many uses and they differ wildly from one another. ${ }^{10}$ Wittgenstein lists some of the tools one might find in a tool-box $\left(1953, \mathrm{I} \S 11, \mathrm{p} .6^{\mathrm{e}}\right)$, not all of which (the rule, the glue-pot) serve to modify anything $\left(\S 14, \mathrm{p} .7^{\mathrm{e}}\right)$. Language does not consist, as logicians may have implied, almost completely of truth-valued statements playing the roles of premises and conclusions in attempts to prove. Wittgenstein was here rejecting precisely the vision of language which had inspired him when he wrote the Tractatus, and which he had shared with Russell:

In a logically perfect language, there will be one word and no more for every simple object, and everything that is not simple

${ }^{10}$ In the Investigations, Wittgenstein listed some of the uses of language:

Giving orders, and obeying them -

Describing the appearance of an object, or giving its measurements -

Constructing an object from a description (a drawing) -

Speculating about an event -

Forming and testing a hypothesis -

Presenting the results of an experiment in tables and diagrams -

Making up a story; and reading it -

Play-acting -

Singing catches -

Guessing riddles -

Making a joke; telling it -

Solving a problem in practical arithmetic-

Translating from one language into another-

Asking, thanking, cursing, greeting, praying.-

It is interesting to compare the multiplicity of the tools in language and of the ways in which they are used, the multiplicity of kinds of word and sentence, with what logicians have said about the structure of language. (Including the author of the Tractatus Logico-Philosophicus.) (Wittgenstein, 1953, I, § 23, pp. $11^{\mathrm{e}}-12^{\mathrm{e}}$.)

The reference to "the author of the Tractatus Logico-Philosophicus" is of course Wittgenstein's somewhat affected way of marking the progress in his own ideas since writing that work. 
will be expressed by a combination of words, by a combination derived, of course, from the words for the simple things that enter in, one word for each simple component. A language of that sort will be completely analytic, and will show at a glance the logical structure of the facts asserted or denied. The language which is set forth in Principia Mathematica is intended to be a language of that sort. It is a language which has only syntax and no vocabulary whatsoever. Barring the omission of a vocabulary I maintain that it is quite a nice language. It aims at being the sort of language that, if you add a vocabulary, would be a logically perfect language. (Russell, 1918, § ii, pp. 197-8.)

That there are different kinds of locutions had in fact been acknowledged by modern logicians since the beginning, even if Russell and the early Wittgenstein had forgotten it:

An interrogative sentence and an assertoric one contain the same thought, but the assertoric sentence contains something else as well, namely assertion. The interrogative sentence contains something more too, namely a request. Therefore two things must be distinguished in an assertoric sentence: the content, which it has in common with the corresponding propositional question; and assertion. (Frege, 1918, p. 329.)

\section{Dummett would later elaborate:}

The theory of sense and reference is then to be supplemented by an account of the various forms of linguistic force that may be attached to a sentence: the theory of force thus supplies an account of the various uses that are actually made of sentences in actual speech. The separation of sense and force can only be justified if it is possible, for each variety of force, to give a uniform description of the linguistic act which is effected by the utterance of an arbitrary sentence, whose truth-conditions are supposed known, to which a force of that kind is attached. There will thus be one general account of the use of sentences to make an assertion, another of their use to ask a sentential question, and so on, each applicable independently of the particular sense and hence the particular truth-conditions of the sentence. (On Frege's own account of the matter, this holds good only for assertions and sentential questions; but, as we have seen, if a theory of meaning of this general structure is possible at all, the procedure should be able to be extended to commands, requests, expressions of desire, etc.) (Dummett, Michael, 1973, p. 416, his emphasis; see also his ch. 10, pp. 259363.)

We may distinguish between asserting, questioning, defining, promising, expressing doubt about, and other kinds of linguistic 
action, each characterised by a kind of Fregean "force". ${ }^{11}$ The crucial relationship between all these kinds of action is one readily recognised by logicians: the relationship between a set $\Gamma$ of statements, say \{"Every human is mortal", "Socrates is human"\}, and another statement $s$, say "Socrates is mortal", such that if a person has agreed to all the statements in $\Gamma$, that person may not subsequently deny, question, express doubt about, or ask for reasons to accept the statement $s$, and must agree to $s$ if asked. (A speaker may, however, remove commitment to one of more of the statements in $\Gamma$ and thereby recover the ability to deny, question, express doubt about, or ask for reasons to accept s.) Logic, that is formal logic, can be thought of as the key to the jungle of varieties of linguistic action found in ordinary language, and conversely logical relations have their function in regulating discourse.

What defines the various kinds of force is precisely the different roles which kinds of sentence have in dialogue: “... it should be borne in mind that it is ultimately their role in the dialectical system that gives sentences this kind of character [scil., as statements or questions] rather than the other way about." $(1970$, p. 257) "In the long run, whether a given locution is or is not a statement, question or the like depends upon its place in a dialectical system, and not vice versa" (1970, p. 259). Indeed, " ... the primary theoretical job that commitment-stores do for us is to provide us with a dialectical definition of statements" (1970, p. 265; compare pp. 285-6).

In "Mathematical models", Hamblin provides inversion algorithms for his systems in which one takes the set $K$ of legal dialogues of the system and defines in terms of it the various semantic properties: kinds of locutions such as statements, questions, retractions; logical relations such as immediate consequence and immediate inconsistency; and a mapping of the locutions of the system onto the set of possible worlds (1971, pp. 150-155). Though inversion algorithms were explicitly provided only for the very restricted toy systems described in that paper, the project was clearly that semantics could, and should, be seen as arising from a similar inversion algorithm for much larger and more complex dialogue systems.

The point is just that, whatever the result of that quest [for a paradox-free theory of deduction], there are various criteria of worth of arguments; that they may conflict, and that arguments

\footnotetext{
${ }^{11}$ As Hamblin said, "The scope of Formal Logic is enlarged when Questions are introduced into it, but it is still not so large as to include the contextual or dialectical concepts that are needed to give a fully-practical account of the Fallacy [of Many Questions]" (1970, p. 217).
} 
may conflict; that when criteria conflict some are more dispensable than others, and that when arguments conflict a decision needs to be made to give weight to one rather than another. All this sets the theory of arguments apart from Formal Logic and gives it an additional dimension. This should now be abundantly clear, and we may turn our attention to the filling-in of details. (1970, p. 231, Hamblin's italics.)

After all, "Dialectical concepts have a certain claim to be considered as the fundamental ones, in that the 'raw' facts of the dialectical situation are that the various participants put forward and receive various statements" $(1970$, p. 242).

Formal logic began with Aristotle, but (as a Popperian) Hamblin must have asked To what problem was formal logic the solution? Further, as a historian he must have asked What was lost when this solution was adopted? Aristotle made a collection of commonplaces of argument in the Topics and of fallacious argument in the Sophistical Refutations, which is in many respects an appendix to the Topics (Hamblin, 1970, p. 11; Kneale $\&$ Kneale, 1962, pp. 23, 43). The source of the examples is often Plato's dialogues, and particularly the Euthydemus (a dialogue sometimes neglected by those who wish to use Plato's works as a source for pompous pronouncements about everything in general and nothing in particular). Aristotle was wrestling with questions to which he would later ${ }^{12}$ propose a systematic solution with the doctrine of the categorical syllogism in the Prior Analytics. That theory is to a startling extent a fully modern theory of deduction. Just how modern Aristotle's treatment there was had not become really clear until Łukasiewicz's Aristotle's Syllogistic (1951). ${ }^{13}$ The categorical syllogism does provide a framework for handling many questions about that kind of dialogue and more generally about the structure of deductive argument which underlies Plato's elenctic dialogues; but not all. As Hamblin noted, the standard logical model of proof completely ignores certain important desiderata, such as forbidding circular reasoning or equivocation $(1970$, p. 249, cf. p. 231; Mackenzie, 1984a, 1988). There remains a residue of questions about how the theory is to be applied to actual cases, and some of these continue in logic textbooks as the unsystematic chapter on falla-

\footnotetext{
12 The Prior Analytics appears before the Topics in the traditional ordering of Aristotle's works but, though the relative dates of Aristotle's works are notoriously difficult to resolve, it is generally agreed to have been written later. "There are many passages in the Topics which anticipate points in Aristotle's syllogistic" (Kneale \& Kneale, 1962, p. 36).
}

${ }^{13}$ This work, with the same writer's paper "On the history of the logic of propositions." (1934), received due emphasis in Hamblin's course on the history of logic. 
cies. Even so, students continued to study the whole Organon, including the arguably superseded Topics, through the Middle Ages and beyond.

As part of the Organon, the Topics continued to influence students of philosophy until the seventeenth century, but we cannot say that it has contributed much to the development of logic, except indirectly through the impulse it gave to the elaboration of the medieval theory of consequentiae (Kneale \& Kneale, 1962, p. 44).

Since Aristotle's time, the progress of logic had consisted overwhelmingly in elaborations of the theory of deduction until logic was seen by some as simply being the theory of deduction "and Topics, though carried for many centuries as an appendage, have finally disappeared from logic books" (Hamblin, 1970, p. 191).

Though the writers of logic books had finally dropped Topics, they had mostly kept Fallacies.

All our modern books identify and name this Fallacy [Affirming the Consequent] but only one, the traditionalist Oesterle, lists it in order with the other Fallacies. The others treat it along with inferences of the calculus of propositions. The divorce between Fallacies and the rest of Logic could hardly be more complete. As soon as a Fallacy has some relation to the rest of Logic it is removed from its place in the chapter on Fallacies! (Hamblin, 1970, p. 36.)

Fallacies kept a place in logic books even though they didn't really fit with the understanding logicians had of logic. "Fallacies have continued to occupy a place in textbooks because they introduce important considerations outside Formal Logic and supplementary to it" (Hamblin, 1970, p. 205). Hamblin's interest in fallacies was that they did precisely this, opening logic to considerations outside and supplementary to it, and thereby showing logic to be different from what it has been generally supposed to be.

Hamblin's view was that the theory of deduction cannot suffice for the theory of argumentation, and that it must be extended "to include features of the context within which arguments are put forward" (1970, p. 254).

One of our first ideas about language is that there are different species of words - nouns, pronouns, adjectives, verbs and so on. As we learn more about language, we come to see that these species, much refined, reappear as categories in terms of which we frame rules; and these rules, from among all possible strings of English words, exclude most as not being sentences. These 
rules are the rules of grammar. Another of our first ideas about language is that there are different species of sentencesstatements, questions, commands, and so on. Were we to learn more about language, we might come to see that these species, much refined, appear as categories in terms of which we frame rules. These rules, from among all possible strings of English sentences, would exclude many as not being intelligible discourses. One such rule, for example, would be some requirement of the idea that questions must be answered. That there should be rules of that kind is necessary if we are to explain how communication - as against independent vocalizers scattered about the landscape uttering sentences at random into the void-is possible. (Mackenzie, 1984, p. 345b, emphasis in original.)

It is in dialogue, the interaction between language users, that an understanding of questions of meaning, communication, validity and indeed mentality are to be sought. Formal dialectic is a study not only of logical issues, but of how to build a machine to speak a language, to converse; and thereby to understand what we language-using animals are. The examination of fallacies was one path by which we might come to see this. ${ }^{14}$

\section{References}

Agassi, Joseph. (2008). The Philosopher's Apprentice: In Karl Popper's workshop. $2^{\text {nd }}$ ed. rev. Amsterdam: Rodopi.

Dummett, Michael. (1973). Frege: Philosophy of Language. London: Duckworth.

Dutilh Novaes, Catarina. (2007). Formalizing Medieval Logical Theories: Suppositio, Consequentiae and Obligationes. Dordrecht: Springer.

Edmonds, David, \& John Eidinow. (2001). Wittgenstein's Poker. London: Faber \& Faber.

Frege, Gottlob. (1892). On sense and reference. Tr. in Peter Geach \& Max Black (Eds.), Translations from the Philosophical Writings of Gottlob Frege, pp. 56-78. Oxford: Basil Blackwell, 1966.

Frege, Gottlob. (1893). Grundgesetze der Arithmetik, begriffsschriftlich abgeleitet Band I. Jena: Verlag Hermann Pohle. (Repr. Hildesheim: Georg Olms Verlagsbuchhandlung, 1962.) Partly translated as The Basic Laws of Arithmetic

\footnotetext{
${ }^{14}$ My recollections of the seminars were helped by discussions with P.J. Staines, though he did not see the final paper and is in no way responsible for its errors.
} 
by Montgomery Furth. Berkeley, CA: University of California Press, 1964; repr. 1967.

Frege, Gottlob. (1918). Thought. Tr. in Michael Beaney (Ed.), The Frege Reader, pp. 325-345. Oxford: Blackwell, 1997.

Gellner, Ernest. (1959). Words and Things. (Repr. Harmondsworth, Middlesex: Penguin Pelican, 1968.)

Groarke, Leo. (2008). Informal Logic, In Edward N. Zalta (Ed.), The Stanford Encyclopedia of Philosophy (Fall 2008 Edition). URL =

$\leq$ http://plato.stanford.edu/archives/fall2008/entries/logicinformal $/>$.

Hacking, Ian. (1979). What is logic? The Journal of Philosophy 26: 285-319.

Hamblin, C.L. (1970). Fallacies. London: Methuen.

Hamblin, C.L. (1971). Mathematical models of dialogue. Theoria 37: 130-155.

Hamblin, C.L. (Ed.) (1984). Languages of Asia and the Pacific. North Ryde, NSW: Angus \& Robertson.

Kneale, William \& Martha Kneale. (1962). The Development of Logic. Oxford: Clarendon Press.

Lessnoff, Michael. (2002). Ernest Gellner and Modernity. Cardiff : University of Wales Press.

Łukasiewicz, Jan. (1934). On the history of the logic of propositions. From Storrs McCall (Ed.), Polish Logic 1920-1939, pp. 66-87. Oxford: Clarendon Press, 1969.

Łukasiewicz, Jan. (1951). Aristotle's Syllogistic: From the standpoint of modern formal logic. Oxford: Clarendon Press, $2^{\text {nd }}$ ed. 1957.

McBurney, Peter. (2008). Charles L. Hamblin: Computer Pioneer. Liverpool: University of Liverpool, Computer Science Department.

McBurney, Peter, I. Rahwan, S. Parsons \& N. Maudet (Eds.). (2010). Argumentation in Multi-Agent Systems. Sixth International Workshop, ArgMAS 2009, Budapest, Hungary, May 2009. Revised, Selected and Invited Papers. Lecture Notes in Artificial Intelligence, volume 6057. Berlin: Springer.

Mackenzie, Jim. (1984). Frege and illogical behaviour. American Philosophical Quarterly 21 (4): 339-348.

Mackenzie, Jim. (1984a). Begging the question in dialogue. Australasian Journal of Philosophy 62: 174-181.

Mackenzie, Jim. (1988). Distinguo: the response to equivocation. Argumentation 2: 465-482.

Mackenzie, Jim, \& Phil Staines. (1999). Hamblin's case for commitment: A reply to Johnson. Philosophy and Rhetoric 32 (1): 14-39.

Magee, Bryan. (1971). Modern British Philosophy Dialogues with philosophers. London: Secker \& Warburg. 
Massey, Gerald J. (1981). The Fallacy behind Fallacies. Midwest Studies in Philosophy 6 (1): 489-500.

Mehta, Ved. (1963). The Fly and the Fly-Bottle. (Repr. Harmondsworth, Middlesex: Penguin, 1965.)

Passmore, John. (1966). A Hundred Years of Philosophy, $2^{\text {nd }}$ ed. (Repr. Harmondsworth, Middlesex: Penguin Pelican, 1968.)

Plato. (tr. 1987). Euthydemus, tr. Robin Waterfield. In Trevor J. Saunders (Ed.), Early Socratic Dialogues, pp. 315-375. London: Penguin, 1987.

Popper, Karl R. (1940). What is dialectic? Repr. in his Conjectures and Refutations, $3^{\text {rd }}$ ed. rev., pp. 312-335. London: Routledge \& Kegan Paul, 1969.

Popper, Karl R. (1959). The Logic of Scientific Discovery. London: Hutchinson.

Popper, Karl R. (1960). On the sources of knowledge and ignorance. Repr. in his Conjectures and Refutations, $3^{\text {rd }}$ ed. rev., pp. 3-30. London: Routledge \& Kegan Paul, 1969.

Popper, Karl R. (1971). Conjectural knowledge: My solution to the problem of induction. Repr. in his Objective Knowledge, pp. 1-31. Oxford: Clarendon Press, 1972.

Popper, Karl R. (1974). Autobiography. In Paul A. Schilpp (Ed.) The Philosophy of Karl Popper, pp. 3-181. La Salle, IL: Open Court.

Quine, W. van O. (1960). Word and Object. Cambridge, MA: M.I.T. Press.

Russell, Bertrand. (1918). The philosophy of logical atomism. Repr. in his Logic and Knowledge, Robert Charles Marsh (Ed.), pp. 177-281. London: George Allen \& Unwin, 1956.

Staines, Phil. (1981). Some formal aspects of the argumentsymbolization relation. Australian Logic Teachers' Journal 5: 1-15.

Staines, Phillip J. (1995). Form, invalidity and the Massey mistake. In Paul Hager \& John Roe (Eds.), Out on a Lemma: Proceedings of the Fourth National Conference on Reasoning, pp. 1-14. Sydney; University of Technology.

Uebel, Thomas. (2010). Vienna Circle. In Edward N. Zalta (Ed.), The Stanford Encyclopedia of Philosophy (Winter 2010 Edition) URL =

$<$ http://plato.stanford.edu/archives/win2010/entries/viennacircle/>. accessed 11 May 2011.

Walton, Douglas N. (1991). Hamblin on the standard treatment of fallacies. Philosophy and Rhetoric 24 (4): 353-361.

Whately, Richard. (1848). Elements of Logic, $9^{\text {th }}$ ed. London; Longman.

Wittgenstein, Ludwig. (1921). Tractatus Logico-Philosophicus, with a new English tr. by D.F. Pears \& B.F. McGuinness. London: Routledge \& Kegan Paul. 


\section{Jim Mackenzie}

Wittgenstein, Ludwig. (1958). The Brown Book. repr. in his The Blue and Brown Books. Oxford: Basil Blackwell, 1958; $2^{\text {nd }}$ ed., 1964.

Wittgenstein, Ludwig. (1953). Philosophical Investigations. With tr. by G.E.M. Anscombe. Oxford: Basil Blackwell, $2^{\text {nd }}$ ed, 1958. 